\title{
PENGARUH MODEL PEMBELAJARAN KOOPERATIF TIPE JIGSAW TERHADAP PENGUASAAN KONSEP DAN AKTIVITAS BELAJAR
}

\author{
Jasmine Salabeela Rumpaka ${ }^{1)}$, Taupik Sopyan ${ }^{2)}$, Romdah Romansyah ${ }^{\text {3) }}$ \\ ${ }^{1}$ Prodi Pendidikan Biologi, FKIP Universitas Galuh Ciamis \\ Email: jasminerumpaka@gmail.com \\ ${ }^{23}$ Prodi Pendidikan Biologi, FKIP Universitas Galuh Ciamis
}

\begin{abstract}
APA Citation: Rumpaka, J. S., Sopyan, T., \& Romansyah, R. (2019). Pengaruh Model Pembelajaran Kooperatif Tipe Jigsaw Terhadap Penguasaan Konsep Dan Aktivitas Belajar. Quagga: Jurnal Pendidikan dan Biologi, 11(2), 79-82. doi: 10.25134/quagga.v11i2.1917.
\end{abstract}

Received: 29-07-2019

Accepted: $30-07-2019$

Published: 30-07-2019

\begin{abstract}
Abstrak: Penelitian ini bertujuan untuk mengetahui Pengaruh Model Pembelajaran Kooperatif Tipe Jigsaw terhadap Penguasaan Konsep dan Aktivitas belajar siswa. Populasi penelitian ini adalah siswa kelas XI IPA SMAN 1 Baregbeg, adapun sampel yang digunakan yaitu kelas XI IPA 2 sebanyak 22 siswa.Teknik pengambilan sampel menggunakan purposive sampling. Metode penelitian ini yaitu metode pre-eksperimental design. Instrumen yang digunakan adalah test penguasaan konsep yang terdiri 20 soal dengan pokok bahasan Sistem Indera dan lembar observasi aktivitas belajar siswa. Teknik analisis yang digunakan adalah uji z. Hasil penelitian ini disimpulkan bahwa model pembelajaran kooperatif tipe jigsaw berpengaruh signifikan terhadap penguasaan konsep dan aktivitas belajar siswa.
\end{abstract}

Kata kunci: Kooperatif Tipe Jigsaw, Penguasaan Konsep Siswa, Aktivitas Belajar Siswa

Abstract: This study aims to determine the Effect of Type Jigsaw Cooperative Learning Model on Mastery of Concepts and student learning activities. The population of this study was students of class XI IPA of SMAN 1 Baregbeg, while the sample used was class XI IPA2 as many as 22 students. The sampling technique used purposive sampling. This research method is the pre-experimental design method. The instrument used is the mastery test concept consisting of 20 questions with the subject of the Sensory System and the observation sheet of student learning activities. The analysis technique used is the z test. The results of this study concluded that the jigsaw cooperative learning model had a significant effect on mastery of concepts and student learning activities.

Keywords: Cooperative Type Jigsaw, Mastery of Student Concepts, Student Learning Activities

\section{PENDAHULUAN}

Pendidikan adalah suatu proses budaya, dimana generasi manusia secara berturut-turut mengambil peranannya dimasa lampau dan masa kini, sehingga menghasilkan peradaban zaman dahulu dan menciptakan peradaban dimasa depan (Munib, et al.2016). Terdapat berbagai masalah terjadi dalam dunia pendidikan, siswa hanya mampu menghafal konsep yang bersifat teori, tanpa ada pengaplikasian konsep dalam penerapan sehari-hari. Dengan demikian hal tersebut menunjukkan bahwa siswa kurang memahami dan mengerti dalam penerapan konsep secara dalam yang telah dihafalnya karena hanya bersifat menghafal tanpa lebih dimengerti. Sehubungan dengan permasalahan tersebut diatas, diperlukan jalan keluar untuk mengatasinya dan untuk mempermudah siswa dalam memahami(Trianto 2007). Berbagai kemampuan dapat dimunculkan dari kegiatan pembelajaran, salah satunya kemampuan dalam aktivitas siswa, kemampuan dalam aktivitas siwa merupakan kemampuan pentin dalam pembelajaran biologi, karena dalam proses pembelajaran biologi siswa dituntut dalam membaca, berdiskusi dan praktek materi biologi dengan baik.Terdapat berbagai materi dalam kurikulum cakupan pembelajaran biologi yang banyak mengandung konsep yang terkadang siswa sulit memahami dan menguasai konsep termasuk materi yang didalamnya terdapat materi yang menyebabkan siswa tidak menguasai dan tidak semangat dalam belajar materi biologi tersebut.

Salah satu model yang dapat digunakan pada proses pembelajaran adalah model Pembelajaran Kooperatif (Cooperative learning). Pembelajaran kooperatif dapat memberikan kesempatan pada peserta didik untuk berinteraksi dan bekerja sama bersama dengan siswa lain dalam suasana 
Quagga: Jurnal Pendidikan dan Biologi

Volume 11, Nomor 2, Juli 2019

bergotong-royong yang harmonis dan kondusif. Susana positif yang timbul dari pembelajaran kooperatif dapat memberikan kesempatan kepada siswa untu mencintai pelajaran, sekolah, serta guru. Dalam kegiatan pembelajaran kooperatif timbul rasa menyenangkan dan mendorong siswa pada proses belajar dan berpikir (Lie, 2002).

Berdasarkan hasil wawancara dengan guru mata pelajaran Biologi kelas XI di SMA Negeri 1 Baregbeg diperoleh informasi bahwa nilai ulangan biologi masih banyak yang belum mencapai KKM (kriteria ketuntasan minimum), adapun KKM di sekolahtersebut sebesar 60.00. Hal ini menunjukkan bahwa kurangnya penguasaan konsep siswa terhadap materi yang disampaikan, sehingga siswa tidak mampu menyelesaikan soal-soal yang diberikan. Berdasarkan referensi bahwa model pembelajaran kooperatif dapat digunakan untuk meningkatkan hasil belajar siswa., seperti yang diungkapkan Wartono et all. (2004) yaitu model cooperative learning tipe Jigsaw. Model pembelajaran kooperatif jigsaw merupakan suatu model pembelajaran yang mampu mendorong siswa aktif dan saling membantu dalam menguasai materi pelajaran sehingga dapat mencapai prestasi yang maksimal. Didalam pembelajaran kooperatif tipe jigsaw mampu menumbuhkan motivasi teman sebaya yang dapat digunakan untuk meningkatkan penguasaan kosep, baik penguasaan kognitif siswa maupun pertumbuhan afektif siswa. Model Jigsaw juga dapat digunakan secara efektif ditiap level dimana peserta didik telah mendapatkan keterampilan akademis dari pemahaman, membaca maupun keterampilan kelompok untuk belajar bersama (Isjoni, 2012).

\section{METODOLOGI PENELITIAN}

Metode penelitian yang digunakan pada penelitan ini adalah Pre-Experimental Design. Desain pada penelitian ini menggunakan oneGroup Pretst-Posttest Design. Populasi penelitian terdiri dari 4 kelas, adapun sampelnya hanya satu kelas yaitu kelas XI IPA2. Instrumen yang digunakan adalah test penguasaan konsep yang terdiri 20 soal dengan pokok bahasan Sistem Indera dan lembar observasi aktivitas belajar siswa

Teknik anlisis data yang digunakan adalah statistika deskriptif, uii normal dan uji z.
p-ISSN 1907-3089, e-ISSN2651-5869

https://journal.uniku.ac.id/index.php/quagga

\section{HASIL DAN PEMBAHASAN}

Hasil penelitian penguasaan konsep dan aktivitas belajar disajikan pada tabel 1 dan 2 di bawah in.

Tabel 1. Statistika data penelitian

\begin{tabular}{cccc}
\hline Kriteria & Pretest & Posttest & N-gain \\
\hline Rata-Rata & 54,55 & 89,32 & 79,17 \\
Nilai Maksimum & 70 & 100 & 100 \\
Nilai Minimum & 40 & 70 & 50 \\
\hline
\end{tabular}

a. Uji Normalitas

Hasil uji normalitas menunjukkan bahwa data normal.

b. Uji hipotesis z

Dapat disimpulkan bahwa penggunaan model pembelajaran kooperatif tipe jigsaw berpengaruh terhadap penguasaan konsep siswa,

c. N-Gain

Dapat disimpulkan bahwa adanya peningkatan penguasaan konsep dengan menggunakan model pembelajaran tipe jigsaw.

d. Aktivitas Belajar Siswa

Ringkasan data hasil observasi aktivitas siswa dengan model pembelajaran kooperatif tipe jigsaw disajikan dalam tabel 2.

Tabel 2. Aktivitas Siswa

\begin{tabular}{|c|c|c|c|}
\hline \multirow[t]{2}{*}{ Komponen } & \multirow[t]{2}{*}{ Indikator } & \multicolumn{2}{|c|}{$\begin{array}{c}\text { Aktivitas Siswa } \\
(\%)\end{array}$} \\
\hline & & Mean & Kriteria \\
\hline $\begin{array}{l}\text { Oral } \\
\text { activities }\end{array}$ & $\begin{array}{l}\text { Mengajukan } \\
\text { pendapat saat diskusi } \\
\text { kelompok } \\
\text { Bertanya berkaitan } \\
\text { dengan materi } \\
\text { pelajaran }\end{array}$ & 86,3 & $\begin{array}{l}\text { Sangat } \\
\text { aktif }\end{array}$ \\
\hline $\begin{array}{l}\text { Mental } \\
\text { activities }\end{array}$ & $\begin{array}{l}\text { Berdiskusi untuk } \\
\text { memecahkan } \\
\text { masalah Berani } \\
\text { mengeluarkan } \\
\text { pendapat }\end{array}$ & 85 & $\begin{array}{l}\text { Sangat } \\
\text { aktif }\end{array}$ \\
\hline $\begin{array}{l}\text { Writting } \\
\text { activities }\end{array}$ & $\begin{array}{l}\text { Mencatat mengenai } \\
\text { materi pelajaran } \\
\text { berdasarkan guru } \\
\text { yang menjelaskan } \\
\text { Siswa menuliskan } \\
\text { hasil diskusi } \\
\text { kelompok }\end{array}$ & 82,5 & $\begin{array}{l}\text { Sangat } \\
\text { aktif }\end{array}$ \\
\hline $\begin{array}{l}\text { Visual } \\
\text { activities }\end{array}$ & $\begin{array}{l}\text { Memperhatikan } \\
\text { ketika kelompok } \\
\text { lain member } \\
\text { jawaban } \\
\text { Memperhatikan } \\
\text { ketika kelompok } \\
\text { lain memberikan } \\
\text { pertanyaan }\end{array}$ & 88,1 & $\begin{array}{l}\text { Sangat } \\
\text { aktif }\end{array}$ \\
\hline
\end{tabular}

Rata-rata skor aktivitas belajar siswa dari seluruh indikator terbut yaitu 85,97 dengan kategori sangan aktif. 
Quagga: Jurnal Pendidikan dan Biologi

Volume 11, Nomor 2, Juli 2019

\section{Pembahasan}

Berdasarkan data hasil penelitian di atas diketahuinilai rata-rata pretest 54,55 , nilai maksimum pretest 70 , nilai minimum pretest 40 . Nilai rata-rata postest 89,32 nilai maksimum postest 100 , nilai minimum postest 70 . Nilai ratarata $\mathrm{N}$-Gain adalah 79,17 nilai maksimum $\mathrm{N}$ Gain adalah 100 nilai minimum N-Gain adalah 50. Maka dapat diketahui bahwa ada peningkatan penguasaan konsep siswa terhadap materi system indera. Untuk mengetahui seberapa besar peningkatan tersebut secara spesifik digunakan rumus $\mathrm{N}$-gain. Dari hasil perhitungan N-Gain yang bahwa indeks-Gain adalah 0,7917dan NGain adalah 79,17 maka criteria tinggi.

Penguasaan konsep siswa mengalami peningkatan $79,17 \%$ (tinggi). Berdasarkan hasil uji normalitas dengan uji $x^{2}$ dapat diperoleh $x_{\text {hitung }}^{2}<x_{\text {tabely }}^{2}$ yaitu $1,439<5,99$. Kemudian untuk mengetahui hipotesis diterima atau ditolak maka dilakukan uji hipotesis dengan menggunakan rumus uji hipotesis $Z$. Berdasarkan perhitungan uji hipotesis $\mathrm{Z}$, dapat diketahui bahwa nilai $Z_{\text {hitung }}>Z_{\text {tabel }}$ yaitu 2,216>1,96, sehingga dapat disimpulkan bahwa model pembelajaran kooperatif tipe jigsaw meningkatkan penguasaan konsep siswa.

Data hasil penelitian menunjukan bahwa penggunaan model kooperatif tipe jigsaw mampu meningkatkan keaktifan siswa, hal ini menunjukan bahwa model tersebut sangat tepat diterapkan dalam pembelajaran karena mampu meningkatkan aktifitas siswa.

Penerapan model pembelajaran kooperatif tipe jigsaw cukup efektif dalam meningkatkan penguasaan konsep dan aktivitas siswa kelas XI IPA 2 SMA Negeri 1 Baregbeg. Riset yang berkaitan dengan pembelajaran kooperatif tipe Jigsaw juga sudah banyak dilakukan dan terbukti dapat meningkatkan kemampuan siswa di kelas. Hal ini sejalan dengan pernyataan Carol (1989) yang menyatakan bahwa pembelajaran yang telah didokumentasikan, meliputi peningkatan self-esteem, hubungan kelompok, komunikasi kooperatif tipe Jigsaw terbukti dapat meningkatkan kemampuan akademik siswa.

Model kooperatif tipe jigsaw merupakan model pembelajaran yang mampu mengajak siswa untuk berpikir secara aktif dan kreatif dalam proses pembelajaran. Model ini tidak hanya mengembangkan kemampuan intelektual saja tetapi seluruh potensi yang ada pada diri siswa, termasuk pengembangan emosional dan pengembangan keterampilan. Dengan menerapkan model ini akan melatih siswa
p-ISSN 1907-3089, e-ISSN2651-5869

https://journal.uniku.ac.id/index.php/quagga

mempunyai keberanian mengemukaan pendapat, bekerja sama, mengembangakan diri, serta bertanggung jawab secara individu, saling ketergantungan positif, interaksi personal dan proses kelompok. Model pembelajaran kooperatif tipe Jigsaw memiliki beberapa kelebihan, diantaranya dapat membantu siswa memahami prosedur pemecahan masalah, pembelajaran menjadi lebih efisien, dan dapat meningkatkan pengalaman belajar siswa (Perkins, 2001).

Berdasarkan beberapa penelitian bidang pendidikan dilaporkan bahwasannya penerapan model pembelajaran kooperatif dapat memotivasi dan melibatkan para siswa dalam proses belajar mengajar untuk meningkatkan hasil belajar. Hasil penelitian lain menunjukan bahwa metode pembelajaran jigsaw dapat meningkatkan prestasi belajar peserta didik pada semua jenjang kelas, mata pelajaran, dan semua tipe pelajar. Banyak hasil, hubungan interpersonal, sikap terhadap sekolah, dan penerimaan serta kemampuan terhadap kerjasama dengan orang lain. Hasil yang positif tersebut meliputi pembelajaran dalam mata pembelajaran biologi, kimia, geologi, staistika, sosiologi, dan psikologi .Pada aktivitas belajar siswa juga disajikan dalam bentuk grafik, dapat dilihat pada gambar1.

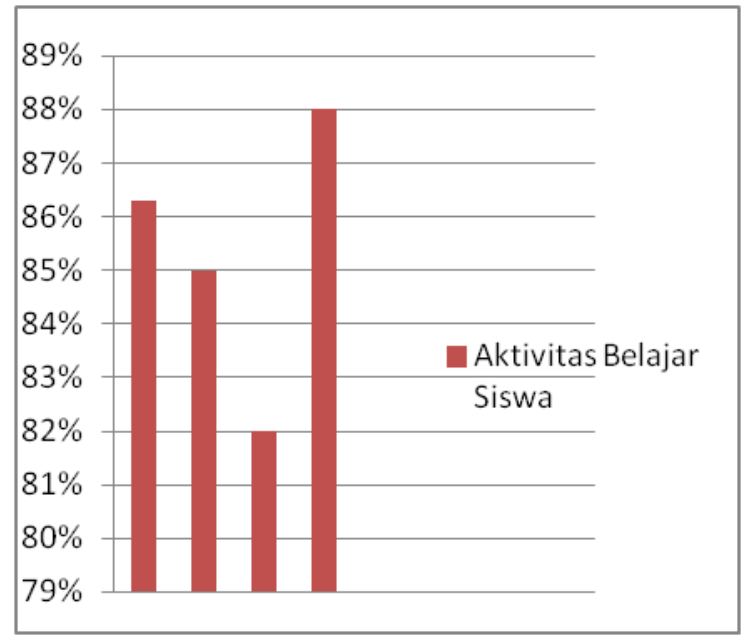

Gambar 1. Grafik Aktivitas Bealajar Siswa

Berdasarkan gambar1 skor yang diperoleh dari setiap indikator berbeda-beda, dengan kategori sangat aktif. Hal tersebut menunjukkan bahwa model pembelajaran kooperatif tipe jigsaw sangat tepat diterapkan dalam pembelajaran karena mampu meningkatkan interaksi siswa dengan lingkungannya. Model pembelajaran ini memiliki kelebihan untuk meningkatkan aktivitas belajar siswa, karena 
Quagga: Jurnal Pendidikan dan Biologi

Volume 11, Nomor 2, Juli 2019

menuntut siswa untuk aktif menyelesaikan suatu proyek dan diterapkan dalam kehidupan seharihari.

Dari hasil analisis observasi siswa, dapat disimpulkan bahwa siswa lebih aktif dalam pembelajaran sistem indera dengan menerapkan model kooperatife tipe jigsaw karena mengajukan pendapat, bertanya, dan berdiskusi untuk memecahkan masalah dalam kehidupan sehari-hari dan dapat membuat siswa lebih mudah dalam memahami materi.

\section{SIMPULAN}

Berdasarkan datahasil penelitian dan analisis data dapat disimpulkan:

1. Penerapan model pembelajaran kooperatif tipe jigsaw berpengaruh terhadap penguasaan konsep siswa pada materi system indera dengan kategori tinggi.

2. Penggunaan model pembelajaran kooperatif tipe jigsaw berpengaruh terhadap aktivitas belajar siswa.

\section{Rekomendasi}

Berdasarkan penelitian maka direkomendasikan hal-hal sebagai berikut:

1. Guru sebaiknya dalam menggunakan model pembelajaran kooperatif tipe jigsaw lebih mempersiapkan secara matang, terkait alokasi waktu untuk masing-masing tahapan

2. Pembelajaran dengan menggunaan model pembelajaran project kooperatif tipe jigsaw membutuhkan waktu yang lama dalam pelaksanaannya. Karena, semakin banyak stimulus yang diberikan kepada siswa semakin banyak pula respon berupa pertanyaan balik. Sehingga, guru harus mampu mengatur waktu dengan baik.

3. Sekolah perlu menerapkan pembelajaran menggunakan model kooperatif tipe jigsaw pada sub materi lain, untuk meningkatkan kualitas pembelajaran siswa.
p-ISSN 1907-3089, e-ISSN2651-5869

https://journal.uniku.ac.id/index.php/quagga

\section{REFERENSI}

Carrol, D W. 1986. Use Of The Jigsaw Technique In Laboratory And Discussion Classes. 13: $208-210$

Isjoni. (2012). Cooperative Learning Efektifitas Pembelajaran Kelompok. Bandung: Alfabeta.

Lie.2002.Cooperative Learning.Jakarta: Gramedia Widiasarana Indonesia.

Munib, A. Budiyono dan suryana, S.(2016). Pengantar Ilmu Pendidikan. Semarang. UNNES Press

Perkins, D, V. 2001."A Jigsaw Classroom Techniquw for Undergraduate Statistics Courses.28: $111-113$

Trianto.2007. Mendesain Model Pembelajaran Inovatif-Progresif. Surabaya. Kencana Prenada Medi Group

Wartono.2004. Materi Pelatihan Terintegrasi Sains. Jakarta: Depdiknas 